\title{
Double Oberlin Procedure and Spinal Accessory Nerve to Suprascapular Nerve Neurotization
}

\author{
Hitesh Inder Singh Rai ${ }^{1} \quad$ Deepak Agrawal',® \\ ${ }^{1}$ Department of Neurosurgery \& Gamma-Knife, All India Institute of \\ Medical Sciences, New Delhi, India
}

Indian J Neurotrauma 2021;18:152-152.

Neurotization or nerve transfer refers to the transfer of a functional nerve to a denervated nerve, in order to recover some function of the injured nerve, thereby converting a high-level injury to a low-level one. ${ }^{1}$ The two most common procedures in the treatment for brachial plexus injuries have been described diagrammatically. Double Oberlin procedure is performed in partial brachial plexus injuries, which involve

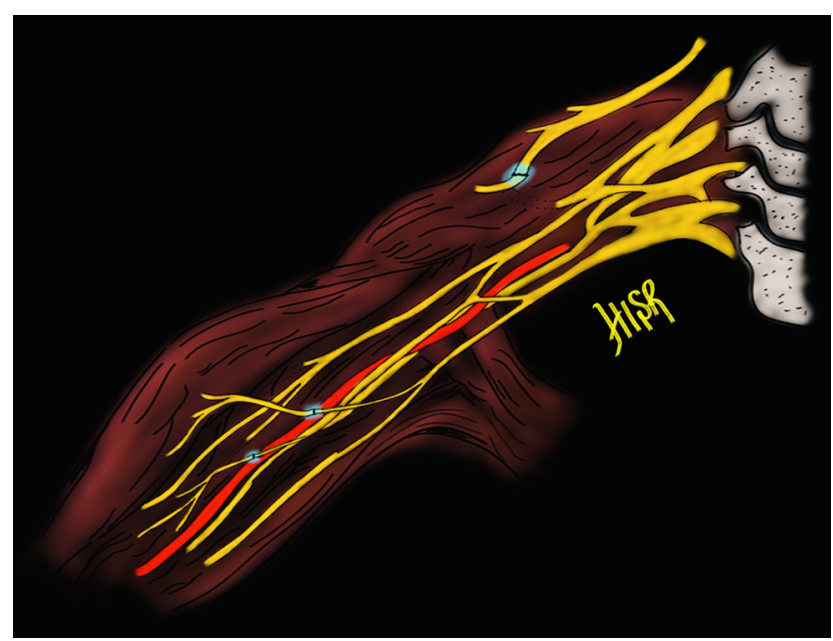

Fig. 1 Right brachial plexus showing double Oberlin procedure and spinal accessory nerve (SAN) to suprascapular nerve (SSN) neurotization.
Address for correspondence Deepak Agrawal, MCh, Department of Neurosurgery \& Gamma-Knife, All India Institute of Medical Sciences, New Delhi 110029, India (e-mail: drdeepak@gmail.com).

injury to musculocutaneous nerve and preservation of function of ulnar and median nerves. ${ }^{2}$ It involves donor fascicle from superolateral portion of ulnar nerve to the nerve to biceps muscle and donor fascicle from medial portion of median nerve to the nerve to brachialis muscle to recover elbow flexion. Another common nerve transfer procedure involves donor fascicle from spinal accessory nerve (SAN) to suprascapular nerve (SSN) to recover shoulder abduction, external rotation and stabilization partially ( - Fig. 1). ${ }^{1}$ Brachial plexus formation and nerve transfers have been shown here with the important nerves and their relation to one another and brachial artery.

\section{Funding}

None.

\section{Conflict of Interest}

None declared.

\section{References}

1 Sinha S, Khani M, Mansoori N, Midha R. Adult brachial plexus injuries: Surgical strategies and approaches. Neurol India 2016;64(2):289-296

2 Texakalidis P, Tora MS, Lamanna J, Wetzel JS, Boulis NM. Double fascicular nerve transfer to musculocutaneous branches for restoration of elbow flexion in brachial plexus injury. Cureus 2019;11(4):e4517 published online July 29, 2021
DOI https://doi.org/

$10.1055 / \mathrm{s}-0041-1732793$ ISSN 0973-0508 (c) 2021. Neurotrauma Society of India.

This is an open access article published by Thieme under the terms of the Creative Commons Attribution-NonDerivative-NonCommercial-License, permitting copying and reproduction so long as the original work is given appropriate credit. Contents may not be used for commercial purposes, or adapted, remixed, transformed or built upon. (https://creativecommons.org/licenses/by-nc-nd/4.0/).

Thieme Medical and Scientific Publishers Pvt. Ltd. A-12, 2nd Floor, Sector 2, Noida-201301 UP, India 